\title{
The blindness, deafness and madness of King George III: psychiatric interactions
}

\author{
${ }^{1} \mathrm{TJ}$ Peters, ${ }^{2} \mathrm{~A}$ Beveridge \\ ${ }^{1}$ Honorary Senior Research Fellow, Institute of Archaeology and Antiquity, University of Birmingham; ${ }^{2}$ Consultant Psychiatrist, \\ Queen Margaret Hospital, Dunfermline, UK
}

\begin{abstract}
Recent research has thrown considerable doubt on the claim that King George III suffered from variegate porphyria, but indicates that he suffered recurrent attacks of mania as part of his bipolar disorder. George III's last episode of ill health occurred during the final decade of his life (I8I0-20). This has been diagnosed as chronic mania with an element of dementia. During this period the king was blind and possibly deaf, which may have contributed to his psychiatric condition. His blindness was due to bilateral cataracts; serious consideration was given at the time to surgery, but this was not carried out.The possible contribution of the king's blindness to his illness is discussed with respect to the roles of his medical attendants. It was also claimed that George III showed progressive deafness and this claim has been re-examined. However, the medical reports by the attending physicians and psychiatrists (mad doctors) do not support this claim.
\end{abstract}

Correspondence to TJ Peters, Iron Lock Cottage, Beeston Brook, Tiverton, Tarporley, Cheshire CW6 9NH, UK

tel. +44 (0) I 2 I 4 I 45497 e-mail timothy@ironlock.f2s.com

KEYWORDS Bipolar disorder, blindness, cataract, chronic mania, deafness, dementia, King George III

DECLARATION OF INTERESTS No conflict of interests declared.

In 1966-69 Ida Macalpine and Richard Hunter, mother and son psychiatrists and historians, claimed on the basis of selective reading and interpretation of the medical and contemporary accounts of King George IIl's illnesses that he suffered from acute intermittent porphyria.' They later changed the diagnosis to the milder and rarer condition variegate porphyria. ${ }^{2}$ Roy Porter advised caution in the interpretation of their findings: 'it is clear that in order to understand the history of psychiatry written by practitioners, it is necessary first to examine their own psychiatric commitments.' Nevertheless, Macalpine and Hunter's view of George IIl's illness has been widely accepted by historians as due to porphyria.

Recent studies by the authors and colleagues, comprising an experienced porphyria clinician, a psychiatrist and medical historians, have presented evidence contesting Macalpine and Hunter's claims. ${ }^{4-6}$

Our re-evaluation of the nature of George Ill's clinical condition has indicated that he most probably suffered from recurrent bipolar disorder, with at least three episodes of acute mania and with chronic mania and possible dementia during the last decade of his life. ${ }^{7}$ This conclusion is in agreement with previous psychiatric evaluations, which concluded that George III suffered from recurrent manic depressive psychosis. ${ }^{8-10}$

\section{BRIEF ACCOUNT OF GEORGE III'S ILLNESSES}

Although George III was born two months premature, his childhood and adolescence seem to have been largely uneventful from a medical viewpoint. His subsequent
TABLE I Principal features of George III's maladies*

\begin{tabular}{|c|c|c|}
\hline Date & Age & Malady \\
\hline 1765 & 27 & $\begin{array}{l}\text { King indisposed Jan-July with chronic } \\
\text { chest infection. Mental health issues } \\
\text { (? depression) largely retrospective. } \\
\text { Regency discussions occurred. }\end{array}$ \\
\hline I788-89 & 50 & $\begin{array}{l}\text { June: Episode of obstructive jaundice } \\
\text { (concretions of the gall duct). Possible } \\
\text { hypomania. October: Relapse with major } \\
\text { psychotic illness (acute mania), remitting } \\
\text { March I789. Regency almost imposed. }\end{array}$ \\
\hline 1795 & 57 & December: Severe bilious attack. \\
\hline$|80|$ & 62 & $\begin{array}{l}\text { January: Relapse of bipolar disorder with } \\
\text { remission by June. }\end{array}$ \\
\hline 1804 & 65 & $\begin{array}{l}\text { February: Relapse of bipolar disorder } \\
\text { with remission by July. Progressive } \\
\text { deterioration of vision, } 1804-08 \text {. }\end{array}$ \\
\hline $1810-20$ & $72-81$ & $\begin{array}{l}\text { October: Persistent relapse with fluctuating } \\
\text { chronic psychosis and possible dementia. } \\
\text { Regency enacted } 6 \text { Feb } 181 \mathrm{I} \text {. }\end{array}$ \\
\hline
\end{tabular}

* Data summarised from refs. 4-7, II and 12

principal illnesses are listed in Table I.The first concerns for his health occurred in 1765, when he had a period of chronic chest disease accompanied by symptoms suggesting a mild degree of depression. Unfortunately, unlike his later illnesses, there are no extant medical notes and the nature of this episode must remain an enigma. That it was significant is emphasised by the fact that following his recovery George III had discussions over possible regency arrangements. ${ }^{13}$ 


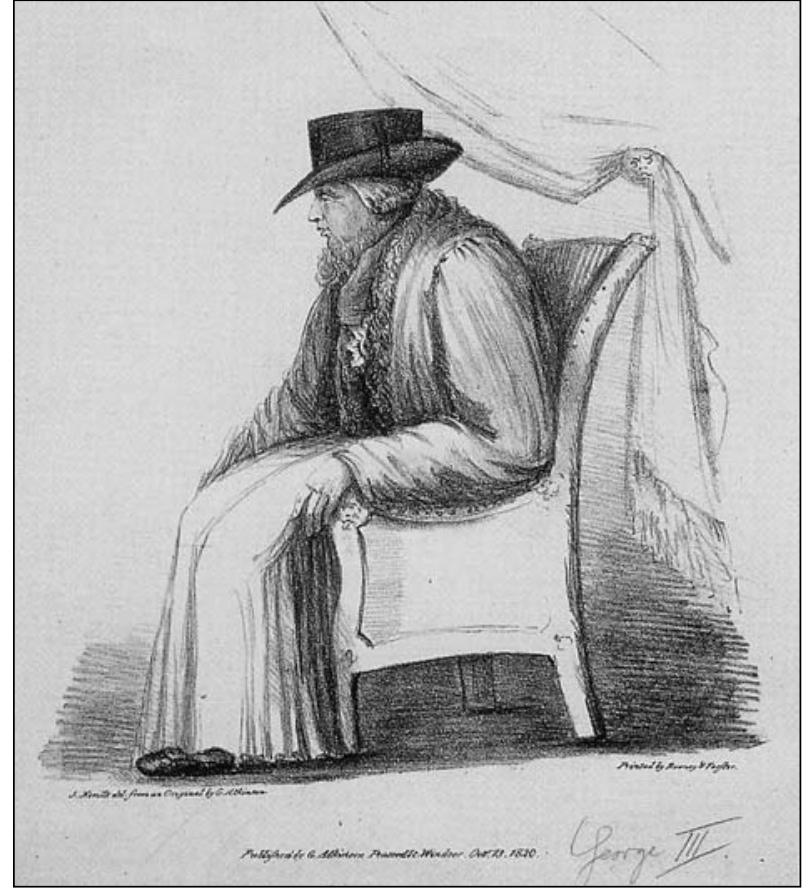

FIGURE I A print of King George III, reproduced with kind permission from Kenneth Baker's George III: a life in caricature. London:Thames and Hudson; 2007.

The king's first and most well-known episode of mental illness occurred between October 1788 and March 1789, at the age of 50.This was a major episode of acute mania lasting almost six months, preceded by an episode of obstructive jaundice (probably cholelithiasis) that may have been the trigger. ${ }^{14}$ It was at this time that the psychiatrists Dr Francis Willis and his sons and their assistants took over the care of the king in this and subsequent episodes of mania. Their apparent success in alleviating George IIl's illness was a major step in the recognition of the developing specialty of psychiatry. The Regency Bill was passed by the House of Commons, but the rapid recovery of the king meant that it was withdrawn during its passage through the House of Lords. ${ }^{15}$

George III recovered and was essentially mentally and physically well until his second episode of mania in January I80I. A further short-lived episode of acute mania occurred in 1804, but there were no regency discussions. From this time the king's vision progressively deteriorated, initially in his right eye and subsequently in his left, and by 1810 he was almost totally blind from bilateral cataracts. On the advice of his prime minister, William Pitt, the king employed a secretary and amanuensis, Sir Herbert Taylor, from 1805 and for the remainder of his active life. ${ }^{16}$

In October 1810, following the death of his favourite daughter Amelia, George III's mental health seriously deteriorated and chronic mania ensued, which lasted with fluctuations until his death in 1820 , aged 81 . The Prince of Wales was sworn in as regent in February 1811 . There is controversy as to whether George III developed significant fatuity (cognitive impairment) during this final decade, but there was little evidence of overall clinical improvement and the regency was subsequently made permanent. ${ }^{17}$

\section{MEDICAL PERSONAE}

A brief résumé of the medical attendants involved in George Ill's care during his latter illnesses follows. These attendants may be conveniently grouped into physicians, including those specialising in psychiatry (the mad doctors), surgeons and apothecaries. Sir Henry Halford was the senior physician involved with the king's care. A distinguished physician educated at Rugby, Oxford and Edinburgh, he practised in London from 1792. He was clearly an astute physician; for example, recognising for the first time the clinical features of hepatic abscesses, most famously in Georgiana, Duchess of Devonshire. In 1809 he was consulted about the chronic chest infection of Princess Amelia during her fatal illness, and subsequently was physician to various members of the royal family. Sir Henry was also an able diplomat and politician and was president of the Royal College of Physicians of London from 1820 to $1844 .^{18}$

The other physicians involved had various degrees of expertise in treating patients with mental illnesses. William Heberden Jr was appointed Physician to the Queen in 1795 and to the King in 1805, but was a general physician with little experience of mental illnesses. Matthew Baillie was a distinguished physician, first consulted by Sir Henry Halford over Princess Amelia's chronic chest infection. In his evidence to the Select Committee of the House of Lords, who examined the physicians concerning the prognosis of George III's illness, he raised the question of the king's fatuity, his age as an adverse factor, and suggested that his blindness would impair recovery. ${ }^{19}$ Henry Reynolds attended George III during his three previous episodes and thus provided some continuity of care. His main function seems to have been to collect details of the fees payable for attendance on the king. His own death was attributed to 'mental anxiety and fatigue of the body and mind' in consequence of his onerous attendance on the king. ${ }^{20}$

The Willis family of specialist mad doctors (psychiatrists) were brought in to care for the king during his four episodes of mental illness. ${ }^{21}$ The father, Dr Francis Willis, was credited with George III's recovery in 1789. He went on to treat, albeit unsuccessfully, Maria I, Queen of Portugal, for a similar mental illness. ${ }^{22}$ His sons, John, Thomas and Robert Darling Willis were involved in the king's care during his various episodes of ill health. The Rev. Thomas Willis was confessor to Queen Charlotte and Rector of St George's, Bloomsbury, and ministered to the king during and between his episodes of illness. He may have been responsible for initially persuading Queen Charlotte to send for the Willis family. 
There was constant friction between the recognised physicians and the Willises. Although John Willis was an Edinburgh medical graduate, he was not considered by Reynolds to be appropriately qualified as a physician and was excluded from consultations. In contrast, the psychiatrists eschewed the physical treatment administered by the apothecaries at the behest of the physicians.

A further doctor consulted with a special interest in mental illness was Samuel Foart Simmons, but when he was not given sole charge of the king he left Windsor. An Edinburgh graduate, Simmons was elected Physician to St Luke's Hospital (asylum) in the City of London in I78I. He was previously consulted about George III's relapses in 1801 and $1804 .^{23}$

Sir David Dundas was appointed Sergeant Surgeon to the King in 1793. He was Household Apothecary at Kew but not officially Apothecary to the King. The Royal Apothecaries who attended the king were Everard Augustus Brande and Robert Battiscombe. ${ }^{24}$ Dundas was a prominent figure in the Royal College of Surgeons and was Master of the College in 1804, I8II and 1819. $\mathrm{He}$ was made a baronet in $1815 . .^{25}$ The king's oculists were Chevalier John Taylor from 1760 to I77I, Baron Michael de Wenzell from 1772 to 1790 and Jonathan Wathen Phipps from 1796 to 1814.

\section{BLINDNESS AND MENTAL ILLNESS}

The physicians discussed the relationship between the king's blindness and his mental illness. In order to find objective evidence they conducted a clinical study, much as would be carried out today. A survey was conducted of eight blind lunatics in St Luke's, Guy's and Bethnal Green hospitals: there was apparently no deterioration when they became blind. ${ }^{26}$ In response to the question by the House of Lords Select Committee - will the king's blindness retard or promote his majesty's recovery? - the response was:

Upon the whole I don't think it rather unfavourable; It has not been found by experience that deranged persons who are blind are more apt to become imbecile from seclusion (than those who see)... ${ }^{19}$

In spite of the apparent lack of a relationship between blindness and madness, surgery for George IIl's cataracts was reconsidered. On 29 June I8II Dundas wrote an incisive report ${ }^{27}$ on the arguments for and against performing surgery on the king's cataract:

Reasons for the King undergoing the operation for extracting the Cataract of the right eye.

If the operation should prove successful it would enable His Majesty to be amused with the surrounding objects, it might lead to a change of place and furnishing new Ideas to his Mind, it might contribute materially to recovery from his present illness Also when His Majesty is declared well He would return to the exercise of His Royal Powers with much greater advantage to himself, \& with more satisfaction to the Public, than if the Operation were deferred till after $\mathrm{He}$ is declared well.

His Majesty's Bodily health is good \& the season is favourable.

Reasons against His Majesty undergoing the operation for extracting the cataract.

At all times such an operation must occasion a very considerable degree of interest to the individual who is to undergo it. It becomes a question whither a greater degree of interest would not be excited, in his Majesty's present state of Nerves \& also how far that might influence his present state of health!

Should the operation prove successful the Joy naturally produced by so desirable an event would certainly produce no small degree of nervous agitation.

On the contrary were the operation unhappily to fail, although His Majesty's Mind is very strong \& he has always in a remarkable degree possessed the 'aqua mens rebus in arduis' [Keep an even mind in steep matters - Horace] yet it is impossible to say what might be the consequences of such disappointment. It is also to be recollected, that the change in His Majesty's Manner... took place when the disease of the eye increased so much as to deprive the King of the means of passing His usual occupations from the almost total loss of sight. It was then that the tranquillity of mind \& a quickness of His Majesty's Manner took place which had not been witnessed before...

Were the operation to prove unsuccessful would a greater degree of blame be attached to those who recommended it, in particular state in which the King now is. ${ }^{27}$

It was decided against surgery, most likely, as it was thought that no benefit to the king's mental illness would ensue. The last reason stated above would also have played a major part in the decision. At that time the physicians, in contrast to the lunacy doctors, all felt that the king was not amenable to reason:

I am of the opinion that in the present state of his Majesty no advantage can be derived from what may be called the Management of His Mind. I believe him to be incapable of being influenced by Reasoning, admonition or Threats. ${ }^{28}$

- Matthew Baillie, Windsor Castle, 24 August I8I I

\section{DEAFNESS AND MENTAL ILLNESS}

There has been some consideration as to the degree of deafness afflicting the king and whether this contributed to his deteriorating mental state by increasing his social isolation. Macalpine and Hunter claimed: 'In 1817 it was 
noticed that he was going deaf and his last source of impressions from the outside world was coming to an end.' ${ }^{29}$ This view has been reiterated in subsequent biographies of George III. 12,30 However, in a report dated II July 1817, Halford and John Willis state:

We have now ascertained it with considerable accuracy that His Majesty's deafness has not materially increased of late. His Majesty's thoughts are sometimes so entirely occupied and engross'd, and His distemper gives rise so frequently to a waywardness that we are not surprised that the attendants should have supposed His Majesty to have suffered an aggravation of this infirmity, but we have had positive proof within the last two days of His Majesty possessing his power of hearing in at least as much force as He has done for many months past. ${ }^{31}$

The presence of possible deafness continued to be of concern to the king's non-medical attendants, but in a report dated 22 January 1819 Halford and Robert Willis state:

... we have had the satisfaction of ascertaining that $\mathrm{His}$ Majesty's deafness is not more considerable than it was and that His perception is as keen and quick as ever. ${ }^{32}$

The king's apparent deafness to his pages probably relates to inattention due to his psychotic state. Certainly his apparent deafness remitted with the improvement in his mental state. ${ }^{33}$

\section{DISCUSSION}

The latter part of the eighteenth and early part of the nineteenth centuries was a period of great change in the recognition, understanding and treatment of mental illness. How much George Ill's illness contributed to and benefited from these changes still remains a matter of debate. In an address to the Royal College of Physicians of London in 1833, entitled On the treatment of insanity, particularly the moral treatment, Halford highlighted the situation of the king:

Both the mind and the body of an insane patient are involved in one common calamity... and becomes an object of terror and of pity to all around him. ${ }^{34}$

Halford also commented on the beneficial effect of music and of religious support in mental illness, features relevant to George III, who found considerable solace when making music. ${ }^{34}$

George III had several possible risk factors for the development of cataracts, including myopia, oral and topical medications, psychiatric disease and episodic diarrhoea and malabsorption. ${ }^{35} \mathrm{He}$ also had a strong family history of cataracts and thus a genetic component is likely. ${ }^{36}$
The relationship between blindness, deafness and mental illness is relevant to current medical practice as well as of historical interest. Blindness itself is said not to have a causal role for mental illness, although sensory deficits may be associated with paranoid disorder. As Kirtley states: It may be concluded that blindness does virtually nothing to the personality. This is also apparently true with respect to other physical disabilities. ${ }^{37}$ This statement refers to congenital and early onset disabilities. Late-onset blindness, especially in association with the psychosocial isolation of deafness, must be a factor in the pathogenesis and prognosis of mental illness, and a recent study by Leo and colleagues concludes that 'when compared with a hearing-impaired control group, impaired sight alone can acutely affect otherwise psychologically healthy individuals. ${ }^{38}$

Although the physicians did not proceed to operate on George III's cataracts, the latter part of the eighteenth century was a period of considerable advance in the surgical management of cataracts. Couching, the displacement of the opaque lens within the anterior chamber, was long practised from ancient times. The development of extraction techniques by Jacques Daviel in 1750 was rapidly taken up in England by the royal oculist Baron Michael de Wenzell and, although couching was still performed by less able itinerant oculists, extraction was the preferred approach, particularly when clinical and financial circumstances allowed for it. It is likely that extraction would have been performed in the king if surgery were undertaken. ${ }^{39}$

The description of the procedure at that time indicates that complete co-operation of the patient was necessary for at least the half minute required for the surgery and for the ten-day post-operative period. ${ }^{40}$ It was unlikely that George III would have been able to comply with these demands. Today these requirements are much less demanding and surgery in the chronic mentally ill is almost routine.

It is clear from this brief account that the treatment of George IIl's final decade of illness was more sympathetic than that which had occurred previously, with the dismissal of the physical and most of the medical treatments. Opiates were used and it is of interest that digitalis was given a therapeutic trial in the king, a treatment used in acute mania by William Withering in 1785. ${ }^{23}$ However, the strict isolation from his family, equerries and personal servants while incarcerated in Windsor Castle would be strongly contraindicated today.

Acknowledgements We are grateful to Dr Hector Maclean for his advice on cataracts and to the library staffs of the Royal National Institute for Blind People, of the Royal College of Physicians of London and of the Royal College of Surgeons of England. 


\section{REFERENCES}

I Macalpine I, Hunter R. The 'insanity' of King George III: a classic case of porphyria. $\mathrm{Br}$ Med J 1966; I:65-7I. doi:10.1136/ bmj.I.5479.65

2 Macalpine I, Hunter R, Rimington C. Porphyria in the royal houses of Stuart, Hanover, and Prussia. A follow-up study of George III's illness. Br Med J 1968; I:7-I8. doi:I0.I I36/bmj. I.5583.7

3 Porter R. Psychiatry and its history: Hunter and Macalpine. In: de Goei L,Vijselaar J, editors. Proceedings of the Ist European Congress on the History of Psychiatry and Mental Health Care. Rotterdam: Erasmus Publishing; 1993. p. 167-76.

4 Peters TJ. George III: a new diagnosis. History Today 2009; 59:4-5.

5 Peters TJ. The madness of King George III: revelations by James Bland Burges of Nantcribba, Montgomeryshire. The Montgomeryshire Collections 2009; 97:63-72.

6 Peters TJ, Wilkinson D. King George III and porphyria: clinical re-examination of the historical evidence. Hist Psychiatry 2010; in press.

7 Peters TJ, Beveridge A. The madness of King George III: a psychiatric re-assessment. Hist Psychiatry 2010; in press.

8 Ray I. The insanity of King George III. Am J Insanity I855; I2:I-29.

9 Guttmacher MS. America's last king. An interpretation of the madness of George III. New York: Scribner's; I 94I.

I0 Brownstein S. George III: a revised view of the royal malady.J Hist Neurosci 1997; 6:38-49. doi:10.1080/09647049709525684

I I Royal College of Physicians of London archives; Baker papers: I788; MS 92-93.

12 Wright C. George III. London: British Library; 2005.

13 Fortescue J, editor. The correspondence of King George III. Vol. I (I760-83). London: Macmillan and co.; 1927-8. p. 73-4.

14 Peters TJ, Sarkany R. Porphyria for the general physician. Clin Med 2005; 5:275-81.

15 Ayling S. George the Third. London: Collins; 1972. p. 329-45.

16 Ayling S. George the Third. London: Collins; 1972. p. 444-7.

17 Hibbert C. George IV Regent and King, I8I I-/830. London: Allen Lane; 1975.

I8 Munk W. The life of Sir Henry Halford, Bart. London: Longmans, Green and Co.; 1895.

19 Royal College of Physicians of London archives: reports from the Committee appointed to Examine the Physicians who have attended His Majesty during his IIInesses; Touching the State of His Majesty's Health; 1810, 1812; MS 2538-43.
20 Munk's Roll, Vol II. London: Royal College of Physicians of London; I70I-I800. p. 299.

21 Haslam MT. The Willis family and George III. Hist Psychiatry 1997; 8:539-53. doi: 10.1I77/0957/54X9700803206

22 Willis C. Two mad monarchs. Royalty Digest Quarterly 2009; 4: 17-24.

23 Smith L. Lunatic hospitals in Georgian England, 1750-/830. London: Routledge; 2007.

24 Matthews LG. The royal apothecaries. London: Wellcome Historical Medical Library; 1967.

25 Cope Z. The Royal College of Surgeons of England. A history. London: Anthony Blond; 1959.

26 British Library: Willis papers; I8I0; add. MS 4I736. f. 8-9, 25.

27 Lambeth Palace Library: Manners-Sutton papers; I8II; MS 2107. f. $7 \mid-2$.

28 Lambeth Palace Library: Manners-Sutton papers; I8II; MS 2107. f.I 33.

29 Macalpine I, Hunter R. George III and the mad-business. London: Allen Lane; 1969.

30 Hibbert C. George III: a personal history. London: Penguin Books; 1998. p. 405.

31 Lambeth Palace Library: Manners-Sutton papers; 1817: MS 2132. f. 143.

32 Lambeth Palace Library: Manners-Sutton papers; I819; MS 2137.f. 43.

33 Anon. The Georgian era: memoirs of the most eminent persons, who have flourished in Great Britain, from the accession of George the First to the demise of George the Fourth. Vol. I. London:Vizetelly, Branston and Co; I83I. p. 86

34 Royal College of Physicians of London archives: Halford H. On the treatment of insanity; I833; MS 2902-5.

35 Harding J, editor. Cataract biochemistry, epidemiology and pharmacology. London: Chapman Hall; 1991.

36 lyengar SK, Klein BE, Klein R et al. Identification of a major locus for age-related cortical cataract on chromosome 6p I2-q 12 in the Beaver Dam Eye Study. Proc Natl Acad Sci U S A 2004; I0I:1448590. doi:I0.1073/pnas.0400778I01

37 Kirtley DD. The psychology of blindness. Chicago: Nelson-Hall; 1975.

38 Leo DD, Hickey PA, Meneghel G et al. Blindness, fear of sight loss, and suicide. Psychosomatics 1999; 40:339-44.

39 Corlett $\mathrm{H}$. 'No small uncertainty': eye treatments in eighteenthcentury England and France. Med Hist 1998; 42:217-34.

40 Wyman AL. Baron de Wenzel, oculist to King George III: his impact on British ophthalmologists. Med Hist 1991; 35:78-88. 